\title{
METHYL BROMIDE FUMIGATION OF WEED SEEDS IN COMPRESSED COCO PEAT
}

\author{
M.S. BULLIANS ${ }^{1}$, V. ALLISON ${ }^{2}$, M. SARTY ${ }^{3}$ and K. GLASSEY ${ }^{3}$
}

${ }^{1}$ Ministry of Agriculture and Forestry, PO Box 2095, Auckland 1140, New Zealand
${ }^{2}$ Ministry of Agriculture and Forestry, PO Box 106231 , Auckland 1143, New Zealand
${ }^{3}$ Ministry of Agriculture and Forestry, PO Box 2526, Wellington 6140, New Zealand

Corresponding author: mark.bullians@maf.govt.nz

In February 2008, weeds were found growing from imported coco peat and a Ministry of Agriculture and Forestry Biosecurity New Zealand response initiated. A controlled trial was undertaken in 2008 to determine if methyl bromide (MeBr) could be used as an effective treatment to devitalise potential weed seeds in compressed coco peat blocks. Five weed species were trialled: Digitaria sanguinalis, Mollugo nudicaulis, Panicum miliaceum, Cleome rutidosperma and Amaranthus viridis. Four replicates were used in the fumigation trial, with each replicate placed inside one of four 128-block pallets of coco peat. Coco peat blocks near the middle of each pallet were removed and split, and weed seeds of all five species placed in the centre of the blocks before the pallets were repacked for fumigation. Results showed seed growth for Mollugo nudicaulis, Panicum miliaceum and Amaranthus viridis after treatment with an application rate of $240 \mathrm{~g} / \mathrm{m}^{3}$ of $\mathrm{MeBr}$ for $72 \mathrm{~h}$. Temperature was maintained above $16^{\circ} \mathrm{C}$. This result indicated that $\mathrm{MeBr}$ fumigation of compressed coco peat is not a sufficient treatment to devitalize all weed seeds in compressed coco peat.

\section{NON-TARGET PLANT DAMAGE FROM PICLORAM AND TRICLOPYR USED FOR CLIMBING SPINDLE BERRY CONTROL IN REGENERATING NATIVE FORESTS}

\author{
T.K. JAMES ${ }^{1}$, A.A. LAURENSON ${ }^{2}$, E.C. CARNEY ${ }^{1}$ and A. RAHMAN ${ }^{1}$ \\ ${ }^{1}$ AgResearch, Ruakura Research Centre, Private Bag 3123, Hamilton, New Zealand \\ ${ }^{2} 4$ Taupo Glade, Joondalup, Perth, Australia \\ Corresponding author: trevor.james@agresearch.co.nz
}

Climbing spindle berry (Celastrus orbiculatus) is a deciduous liane climbing to $12 \mathrm{~m}$. It is spreading in Waikato, particularly in hedgerows and native forest remnants. Control has been by foliar spray with a herbicide mixture containing picloram. This study investigated damage to surrounding non-target native flora where climbing spindle berry was treated with herbicides containing picloram. The most abundant native species in the plots included Podocarpus totara, Blechnum blechnoides, Asplenium bulbiferum, Coprosma spathulata, Carex sp., Adiantum cunninghamii, Pittosporum eugenioides, Deparia petersenii and Lastreopsis glabella. Picloram + triclopyr (Tordon ${ }^{\circledR}$ Brushkiller, $100 \mathrm{~g} /$ litre picloram as the amine salt $+300 \mathrm{~g} /$ litre triclopyr as the butoxyethyl ester) as a foliar spray was compared with picloram gel as a cut stump treatment. Both the cut stump and foliar spray resulted in excellent control of climbing spindle berry. The cut stump treatment resulted in little damage to adjacent vegetation. The foliar spray was damaging to adjacent small non-target plants, especially the ferns. The affected nontarget plants recovered within 6 months with no damage apparent on new growth. This study coincided with a protracted drought and seedling recruitment was compromised; therefore it was difficult to obtain conclusive results about seedling emergence. 